\title{
Profile of mRNA Expression of IL- 6 and IL-10 in Breast Cancer Patients with or Without Chemotherapy
}

\author{
Victor Pontoh ${ }^{1}$, Daniel Sampepajung ${ }^{2}$, Andi Asadul Islam ${ }^{3}$, Mochammad Hatta $^{4}$ \\ ${ }^{1}$ Department of Surgery, Kandou Hospital of Medical Faculty, Sam Ratulangi University, Manado, Indonesia \\ ${ }^{2}$ Department of Surgical Oncology, Faculty of Medicine, Hasanuddin University, Makassar, Indonesia \\ ${ }^{3}$ Department of Surgery, Faculty of Medicine, Hasanuddin University, Makassar, Indonesia \\ ${ }^{4}$ Molecular Biology and Immunology Laboratory, Faculty of Medicine, Hasanuddin University, Makassar, Indonesia
}

\section{Email address:}

hattaram@indosat.net.id (M. Hatta)

\section{To cite this article:}

Victor Pontoh, Daniel Sampepajung, Andi Asadul Islam, Mochammad Hatta. Profile of mRNA Expression of IL-6 and IL-10 in Breast Cancer Patients with or Without Chemotherapy. American Journal of Clinical and Experimental Medicine. Vol. 3, No. 3, 2015 , pp. 99-104. doi: 10.11648/j.ajcem.20150303.15

\begin{abstract}
Background: Breast cancer is a type of cancer that has a high prevalence, can occur in men and women. Cytokines are factors that are known to have good properties of tumor growth and tumor inhibitory effects. Cytokine has an important role in the control of the immune system. Development of breast carcinoma is closely related to mRNA expression of IL-6 as pro-inflammatory cytokine and mRNA expression of IL-10 as anti-inflammatory cytokine. Purpose: Examine changes in mRNA expression of proinflammatory cytokine and anti-inflammatory cytokine in breast cancer patients with or without chemotherapy. Method: This is a case-control study, 12 subjects with breast cancer with chemotherapy as case group and 12 subjects with breast cancer without chemotherapy as control group. In this study we using PCR and RFLP techniques to detect polymorphisms in IL-6 and IL-10 gene. Results: In RFLP analysis, found that IL-6 and IL-10 gene were not polymorphic in all subjects for both case and control groups. Mean value of IL-6 mRNA on breast cancer patients without receiving chemotheraphy was $10.84 \pm 0.48$ whereas on breast cancer patients with chemotherapy was $6.28 \pm 1.19$. Mean value of IL-10 mRNA on breast cancer patients without receiving chemotheraphy was $6.76 \pm 0.81$ whereas on breast cancer patients with chemotherapy was $9.81 \pm 1.07$. The mean value of IL- 6 mRNA on breast cancer patients without receiving chemotheraphy was statistically significant higher than in patients with chemotheraphy. In contrast, mean value of IL-10 mRNA on breast cancer patients without receiving chemotheraphy was statistically significant lower than in patients with chemotherapy. Conclusion: Combination of chemotherapy docetaxel, adriamycin, cyclophosphamide cause a decrease in mRNA expression of IL-6 and an increase in the expression of mRNA of IL-10 in patients with breast cancer.
\end{abstract}

Keywords: Breast Cancer, Chemotherapy, mRNA IL-6, IL-10

\section{Introduction}

Breast cancer is a type of cancer that has a high prevalence in the world . It is estimated that in 2012 the world's incident 1,676,633 cases with mortality 521,817. In Asia Pacific region estimated 403,876 cases of breast cancer with a mortality rate of 115,863 . In Southeast Asia estimated 107,545 cases with a mortality rate 42,003 . In Indonesia 48.998 cases of breast cancer with a mortality rate 19.750 [1].

Breast cancer is a heterogeneous disease with numerous genetic, molecular and cellular characteristics [2]. Interleukins play a major role in many solid cancers pathogenesis. Polymorphisms in interleukins genes are thought to influence the expression or function of these proteins and many have been evaluated for their role in inflammatory disease and cancer predisposition [3]. Interleukins are regulatory proteins that modulates immune response by stimulating or inhibiting the activation, proliferation, and/or differentiation of target cells. Different Interleukins are known to have diverse role in breast cancer initiation and progression [4].

Elevated interleukin 6 (IL-6) and interleukin 10 (IL-10) serum concentration, are strongly associated with breast cancer and correlate with clinical stage of disease. Interleukins may stimulate cancer cells growth and contribute to locoregional relapse as well as metastasis [5].

The interleukin-6 (IL-6) plays an important role in the 
process of inflammation, particularly in the transition from acute to chronic inflammation. In breast cancer, IL-6 has been shown to inhibit the growth of cancer cells but promote the development of metastases [6] [7]. Interleukin-10 is a multifunctional cytokine with both immunosuppressive and antiangiogenic functions. Interleukin 10 is a potent immunoregulatory cytokine. It inhibits some cell functions, including T-helper (Th1) cell activity, and stimulates other functions such as a natural killer (NK) activity [8]. Polymorphisms in the IL-10 gene promoter genetically determine the differences in IL-10 production [9] [8]. Interleukin-10 is an immunosuppressive cytokine which responsible for development of cancer by supporting tumor escape from the immune response [10]. Interleukin-10 may be regulated by a complex monocyte and macrophagederived cytokine network and an impairment of the immune system can be observed in neoplastic disease [11].

The aim of this study was to evaluate mRNA expression and polymorphism of interleukin- 6 and Interleukin-10 in a case control model to determine any associations with breast cancer patients chemotheraphy.

\section{Materials and Method}

\subsection{Collection of Samples}

A matched case-control study was conducted within a population of breast cancer patients who had been diagnosed through clinical and histopathology examination, which entered the Prof. Dr. RD. Kandou Hospital and Network education hospitals in Manado, North Sulawesi, Indonesia. All samples who fulfilled inclusion and exclusion criteria and willing to participate in the study and signing informed consent. The case group consisted of 12 patients with breast cancer who have undergone combinations chemotherapy (combination of docetaxel, adriamycin and cyclophosphamide). The control group was 12 patients with breast cancer who did not receive any chemotherapy.

\subsection{Nucleic Acid Isolation}

Nucleic acid was extracted from breast cancer tissue according to the diatom guanidinium isothiocyanate ( $\mathrm{GuSCN}$ ) method described by Boom et al. 1990. Breast cancer tissue was mixed with $500 \mu \mathrm{l}$ of lysis buffer L6 (50mMTris-HCl, 5.25M GuSCN, 20mM EDTA, 0.1\% Triton X100), vortexes vigorously, and centrifuged at $1,000 \mathrm{rpm}$ for $5 \mathrm{~min}$. To obtain the nucleic acid, samples were lysed by incubation for 15 minutes at $18^{\circ} \mathrm{C}$ and $20 \mu \mathrm{l}$ of diatom suspension was added. The diatom containing the bound nucleic acid was centrifuged at $12,000 \times \mathrm{g}$ for 15 seconds to obtain diatom pellet. The diatom pellet was then washed with washing buffer L2 (5.25M GuSCN in 0.1M Tris-HCl, pH6.4), rinsed with $70 \%$ ethanol and acetone, and dried byincubation at $56^{\circ} \mathrm{C}$ for 10 minutes. The pellet was mixed with $60 \mu \mathrm{l}$ of $10 \mathrm{mM}$ Tris- $\mathrm{HCl}, \mathrm{pH} 8.0,1 \mathrm{mM}$ EDTA buffer and the nucleic acid was eluted by incubation at $56^{\circ} \mathrm{C}$ for 10 minutes. After sedimentation of the diatom by centrifugation, the supernatant was collected and stored at $-20^{\circ} \mathrm{C}$ until RealTime PCR was performed [12].

\subsection{Polymorphisms of IL6 and IL10 Genes by RFLP-PCR Method}

Detection of polymorphisms IL-6 and IL-10 genes was done according to RFLP PCR [13]. Primer set for IL6 gene were used IL6 F: 5'-GGAGTCACACACTCCACCT-3' and IL6 R: 5'-CTGATTGGAAACCTTATTAG-3' with enzyme restriction is Nla III. Primer set for IL 10 gene were use IL10 F: 5'-CTCACTATAAAAATAGAGACGG -3'); IL10 R : C (5'-CTGGCTTCCTACAGG- 3') allel; IL10 R : A (5'-GAC TGGCTTCCTACAGT-3') allel with restriction enzyme Ssp I. All PCR product were run in 1\% agarose gel electrophoresis and visualized by ultraviolet light.

\subsection{Expression mRNA IL6 and IL6 Genes by Real Time PCR}

Detection of mRNA expression of IL6 and IL10 was done according to Real time PCR method previously describe by Annapaula G, 2011 and Yajima T, 1998 [14, 15]. Specific primers for mRNA IL-6 were used IL-6 forward: CTGTTGACAAGCAATGAGACGATGAGG and IL-6 reverse: GAGGATACCACTCCCAACAGACC. Cycle RT PCR for IL- 6 was $94^{\circ} \mathrm{C}$ for 3 minute; $94^{\circ} \mathrm{C}$ for 30 second 38 cycles and next step is PCR: $51^{\circ} \mathrm{C}$ for 30 second; $72^{\circ} \mathrm{C}$ for 30 second. Specific primers for IL10 were used primer IL10 forward: GGTTGCCAAGCCTTATCGGA and IL 10 Dan IL 10 reverse: ACCTGCTCCACTGCCTTGCT. Cycle RT PCR for IL-6 was $94^{\circ} \mathrm{C}$ for 3 minute; $94^{\circ} \mathrm{C}$ for 30 second for 32 cycles and next step is PCR: $52^{\circ} \mathrm{C}$ for 30 second; $72^{\circ} \mathrm{C}$ for 40 second. Also, specific primers of GAPD were used GAPDH forward: AGAGGGAAATCGTGCGTGAC and GAPDH reverse: CAATAGTGATGACCTGGCCGT.

\subsection{Data Analysis}

Data analysis using the SPSS (Statistical Package for Social Science) version 22

\subsection{Ethical Clearence}

Ethical approval for this study was obtained from Research Ethics Committee, Faculty of Medicine Unsrat Manado, Indonesia.

\section{Results}

During the period from January to February 2015 acquired research subjects were 24 patients with breast cancer which meet the inclusion criteria. Within 24 patients with breast cancer consisted of 12 patients breast cancer that have not received chemotherapy and 12 patients who had neoadjuvant chemotherapy or adjuvant combination docetaxel with adryamicin and cyclophosphamide. Minimum age of subject was 38 years and maximum was 67 years old, the mean age of subjects in this research was 52.5 years. Within 24 subject in this research there were 17 subject found in stage III (A/ B) 
and 7 patients with stage IV. In RFLP analysis, found that IL-

6 and IL-10 gene were not polymorphic in all subject for

both case and control groups.

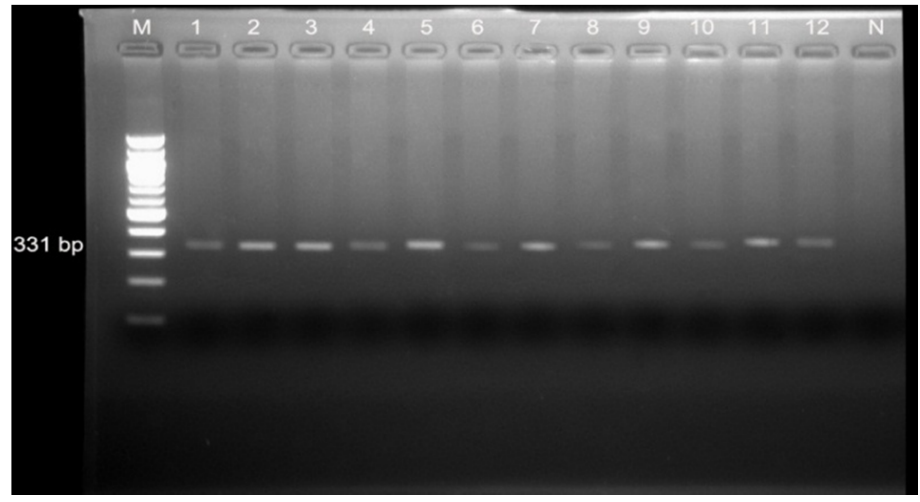

Figure 1. Result PCR RFLP of locus 174 G/C IL6 (rs 1800795) and restricted by Nla III in breast cancer patients without receiving chemotherapy.

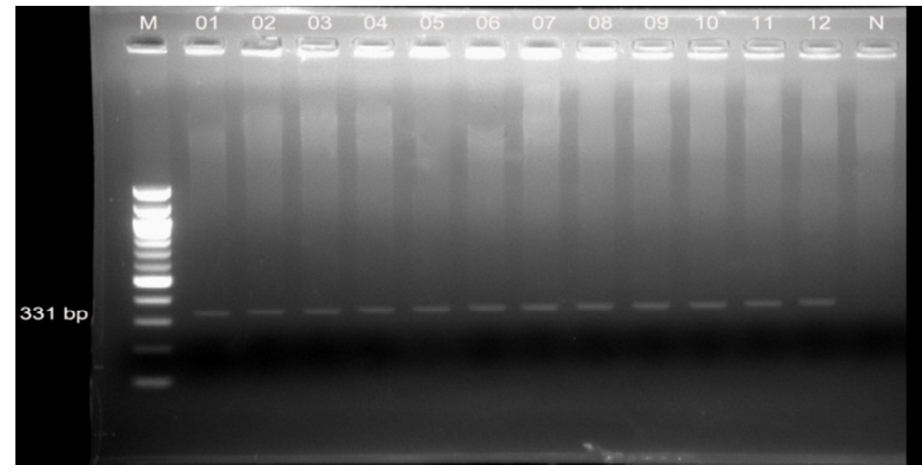

Figure 2. Result PCR RFLP of locus 174 G/C IL6 (rs 1800795) and restricted by Nla III in breast cancer patients after receiving chemotherapy.

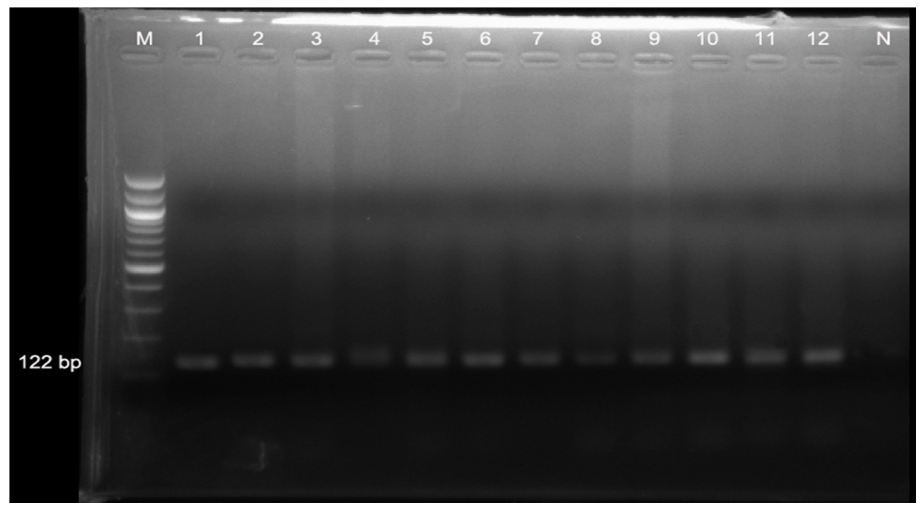

Figure 3. Results PCR RFLP of locus 592 C/A IL10 (rs 1800872) and restricted by Ssp I in breast cancer patients without receiving chemotherapy.

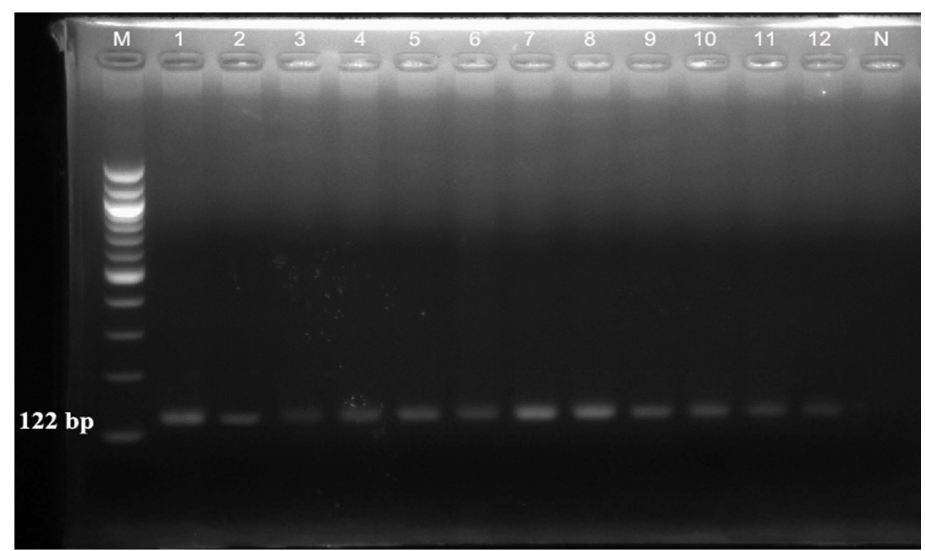

Figure 4. Results PCR RFLP of locus 592 C/A IL10 (rs 1800872) and restricted Ssp I in breast cancer patients after receiving chemotherapy. 


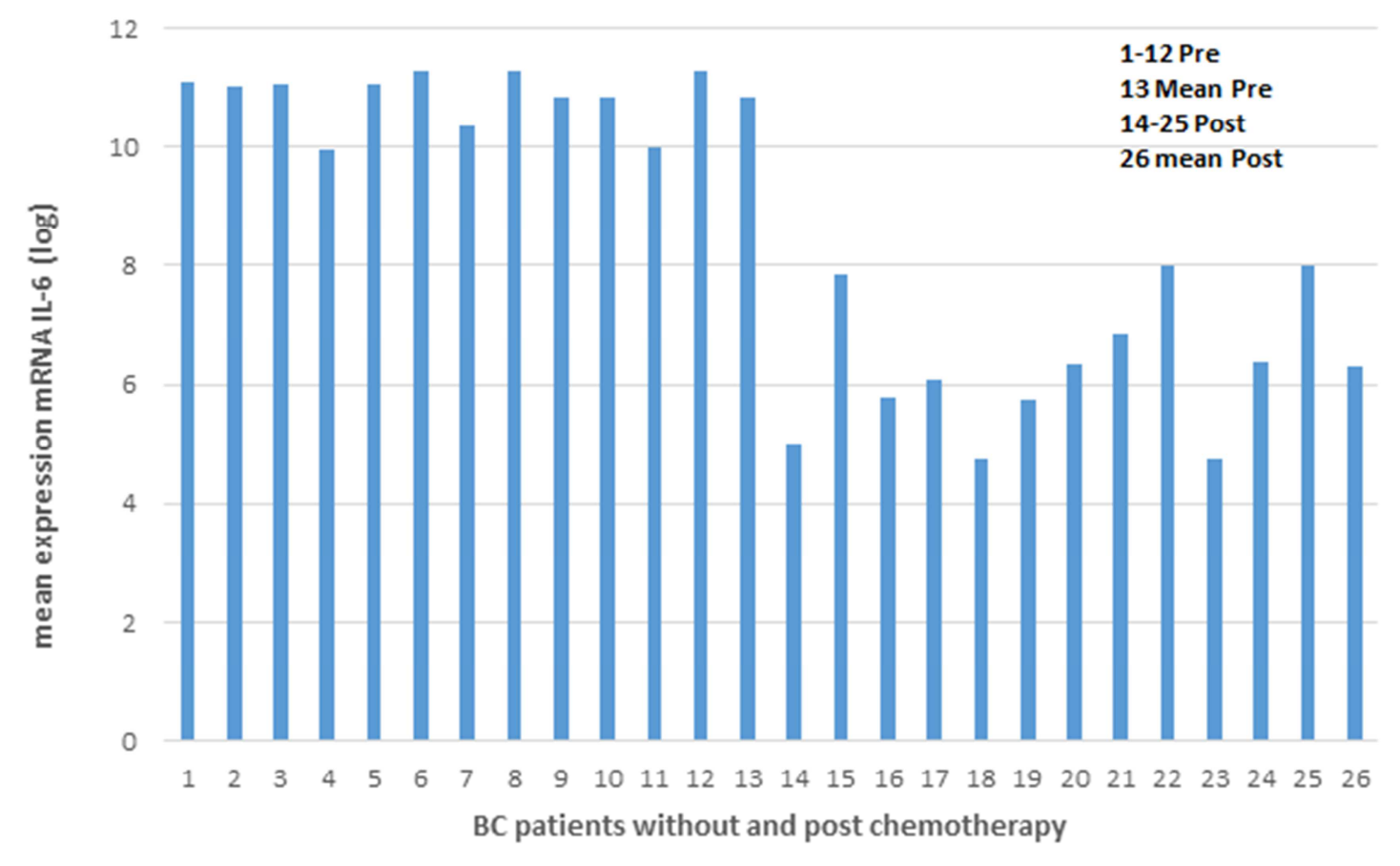

Figure 5. Expression mRNA IL-6 without and post chemotherapy.

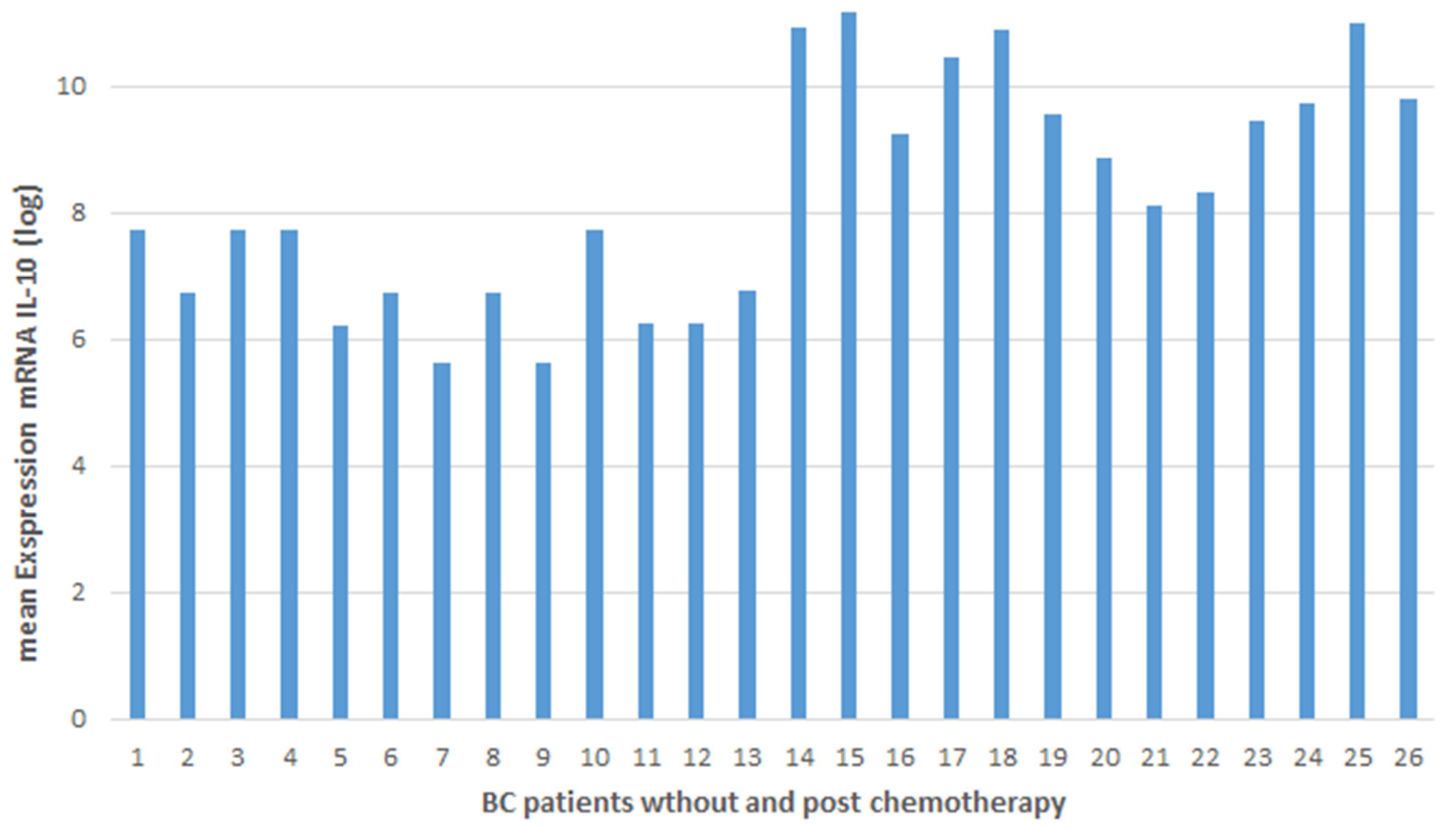

Figure 6. Expression mRNA IL-10 without and post chemotherapy.

Figure 5 shows the mean of IL- 6 mRNA expression was lower in breast cancer patients who have received chemotherapy compared to the mean mRNA expression of IL-6 in breast cancer patients without chemotherapy. Figure 6 shows the mean IL-10 mRNA expression was higher in patients who have received chemotherapy than the mean of
mRNA expression of IL-10 in breast cancer patients without chemotherapy.

Mean value of IL-6 mRNA on breast cancer patients without receiving chemotheraphy was $10.84 \pm 0.48$ whereas on breast cancer patients with chemotherapy was $6.28 \pm 1.19$ shown in table 1. Mean value of IL-10 mRNA on breast cancer patients 
without receiving chemotheraphy was $6.76 \pm 0.81$ whereas on breast cancer patients with chemotherapy was $9.81 \pm 1.07$ shown in table 1 . The mean value of IL-6 mRNA on breast cancer patients without receiving chemotheraphy was statistically significant higher than in patients with chemotheraphy $(p<0.001)$. In contrast, mean value of IL-10 mRNA on breast cancer patients without receiving chemotheraphy was statistically significant lower than in patients with chemotherapy $(p<0.001)$. The magnitude of the difference in average mRNA expression of IL- 6 was 4.84 or mRNA expression of IL- 6 in the chemotherapy group had $43.8 \%$ lower than the group without chemotherapy (Table 1) . The magnitude of the difference in average mRNA expression of IL-10 was 3.05 or mRNA expression of IL-10 in the chemotherapy group had $45.3 \%$ higher than the group without chemotherapy (Table 1) .

Table 1. Comparison expression mRNA expression of IL-6 in Breast Cancer patients without and after chemotherapy.

\begin{tabular}{lll}
\hline \multirow{2}{*}{ Variable } & \multicolumn{1}{l}{ Breast Cancer patients } & \\
\cline { 2 - 3 } & without chemotherapy $(\mathbf{n}=\mathbf{1 2})$ & After chemotherapy $(\mathbf{n}=\mathbf{1 2})$ \\
\hline mRNA expression of IL-6 $(\log )$ & $10.84 \pm 0.48$ & $6.29 \pm 1.19$ \\
mRNA expression IL-0 $(\log )$ & $6.76 \pm 0.81$ & $9.81 \pm 1.07$ \\
\hline
\end{tabular}

\section{Discussion}

In the case-control study, we found 24 patients with breast cancer, of all these patients, there were 12 patients received neoadjuvant or adjuvant chemotherapy combinations; class taxane (docetaxel), Adriamycin (Doxorubicin) and Cyclophosphamide, and 12 patients without received chemotherapy for breast cancer. In RFLP analysis, we found that IL-6 and IL-10 gene were not polymorphic in all subject for both case and control groups. In breast cancer, high levels of the inflammatory cytokine IL-6 have been associated with disease-free survival and treatment resistance[16]. Study on interleukin-6 gene promoter and influence of $-174 \mathrm{G} / \mathrm{C}$ polymorphism on breast cancer reveal that was no association or trend of association between -174G/C polymorphism of IL- 6 gene promoter gene and breast cancer diagnosis or prognosis was shown, even in meta-analyses [17]. The results of this study differs from previous study that found polymorphisms in the IL-10 (rs1800872) has a relationship with breast cancer risk[18]. Other study on association of breast cancer and polymorphisms of IL-10 suggest that the IL-10AA genotype is correlated with a marked increase in breast cancer risk [19]. A study in Chinese population reported that the IL-10 promoter polymorphisms were significantly associated with the progression of breast cancer [9]. Another different result from a meta-analysis study suggests a lack of association between the two SNPs (rs1800896 and rs1800872) in the IL-10 gene promoter and breast cancer risk [20].

In this study we observed an association of levels IL-6, and IL-10 in breast cancer patients with or without receiving chemotheraphy. The high proinflammatory cytokine IL-6 mRNA expression in 12 patients without chemotherapy was 10.8447 ( $\log$ mean) due to the production of cancer cells and cells surrounding the tumor tissue [21]. Previous study indicated that inflammation within the tumor microenvironment may play an important role in breast cancer progression [22]. The mean value of IL-6 mRNA on breast cancer patients without receiving chemotheraphy was statistically significant higher than in patients with chemotheraphy. Previous study on breast cancer patients treated with tamoxifen and Supplemented with Co-Enzyme
Q 10, riboflavin and niacin suggests that serum levels of IL-6 which are stimulators of angiogenesis as well as factors for cancer cell proliferation and growth are reduced after treatment. This study supported by other study on prostate cancer, reported that significant association between high IL6 in sera of prostate cancer patients and decreased response to docetaxel [23].

In this study, mean value of IL-10 mRNA on breast cancer patients without receiving chemotheraphy was statistically significant lower than in patients with received chemotherapy. Interleukin 10 is a potent cytokine, inhibits some cell functions, including T-helper cell activity and stimulates natural killer activity. In a murine model study suggested that IL-10 has antitumor and antimetastitic properties in mice, possible use of IL-10 in the treatment of human metastatic cancers [8]. Study on Interleukin-12 and interleukin-10 production by mononuclear phagocytic cells from breast cancer patients show that mononuclear cells of patients affected by breast cancer have a defective IL-12 production capability while generating higher amounts of IL-10 [11].

In this study we concluded that combination of chemotherapy docetaxel, adriamycin, cyclophosphamide cause a decrease in mRNA expression of IL-6 and an increase in the expression of mRNA of IL-10 in patients with breast cancer.

\section{References}

[1] Danny R. Youlden, Susanna M. Cramb, Cheng Harip, Baade P: Incidence and mortality of female breast cancer in the AsiaPacific region,. Brisbane 4000, Australia.; 2014.

[2] Quan L, Gong Z, Yao S, Bandera EV, Zirpoli G, Hwang H, Roberts M, Ciupak G, Davis W, Sucheston L et al: Cytokine and cytokine receptor genes of the adaptive immune response are differentially associated with breast cancer risk in American women of African and European ancestry. International journal of cancer Journal international du cancer 2014, 134(6):1408-1421.

[3] Balasubramanian SP, Azmy IA, Higham SE, Wilson AG, Cross SS, Cox A, Brown NJ, Reed MW: Interleukin gene polymorphisms and breast cancer: a case control study and systematic literature review. BMC cancer 2006, 6:188. 
[4] Hamidullah, Changkija B, Konwar R: Role of interleukin-10 in breast cancer. Breast cancer research and treatment 2012, 133(1):11-21.

[5] Kozlowski L, Zakrzewska I, Tokajuk P, Wojtukiewicz MZ: Concentration of interleukin-6 (IL-6), interleukin-8 (IL-8) and interleukin-10 (IL-10) in blood serum of breast cancer patients Roczniki Akademii Medycznej w Bialymstoku 2003, 48:82-84.

[6] Dossus L, Kaaks R, Canzian F, Albanes D, Berndt SI, Boeing H, Buring J, Chanock SJ, Clavel-Chapelon F, Feigelson HS et al: PTGS2 and IL6 genetic variation and risk of breast and prostate cancer: results from the Breast and Prostate Cancer Cohort Consortium (BPC3). Carcinogenesis 2010, 31(3):455-461.

[7] Reed MJ, Coldham NG, Patel SR, Ghilchik MW, James VH: Interleukin-1 and interleukin-6 in breast cyst fluid: their role in regulating aromatase activity in breast cancer cells. The Journal of endocrinology 1992, 132(3):R5-8.

[8] Kundu N, Beaty TL, Jackson MJ, Fulton AM: Antimetastatic and antitumor activities of interleukin 10 in a murine model of breast cancer. Journal of the National Cancer Institute 1996, 88(8):536-541.

[9] Kong F, Liu J, Liu Y, Song B, Wang H, Liu W: Association of interleukin-10 gene polymorphisms with breast cancer in a Chinese population. Journal of experimental \& clinical cancer research : CR 2010, 29:72.

[10] Woo SU, Bae JW, Yang JH, Kim JH, Nam SJ, Shin YK: Overexpression of interleukin-10 in sentinel lymph node with breast cancer. Annals of surgical oncology 2007, 14(11):32683273.

[11] Merendino RA, Gangemi S, Misefari A, Arena A, Capozza AB, Chillemi S, D'Ambrosio FP: Interleukin-12 and interleukin-10 production by mononuclear phagocytic cells from breast cancer patients. Immunology letters 1999, 68(2-3):355-358.

[12] Boom R SC, Salimans MM, Jansen CL, Wertheim-van DillenPM, van der Noordaa J,: Rapid and simple method forpurification of nucleic acids. J ClinMicrobiol 1990, 29(496-503).

[13] Camil L. Bohiltea, Radoi. VE: Interleukin-6 and interleukin10 gene polymorphisms and recurrent pregnancy loss in Romanian population. Iran J Reprod Med 2014, 12(9):617622 .

[14] Annapaula Giulietti, Lut Overbergh, Dirk Valck, Brigitte Decallonne, Roger Bouillon, Mathieu C: An Overview of Real-Time Quantitative PCR: Applications to Quantify Cytokine Gene Expression. . Methods 2001, 25:386-401.
[15] Yajima T, Atsuhito Yagihashi, Daisuke Furuya, Kameshim H: Quantitative reverse transcription-PCR assay of the RNA component of human telomerase using the TaqMan fluorogenic detection system. Clinical chemistry 1998, 44(12):2441-2445.

[16] Markkula A, Simonsson M, Ingvar C, Rose C, Jernstrom H: IL6 genotype, tumour ER-status, and treatment predicted disease-free survival in a prospective breast cancer cohort. BMC cancer 2014, 14:759.

[17] Cherel M, Campion L, Bezieau S, Campone M, Charrier J, Gaschet J, Ricolleau G, Gouraud W, Charbonnel C, Jezequel P: Molecular screening of interleukin-6 gene promoter and influence of $-174 \mathrm{G} / \mathrm{C}$ polymorphism on breast cancer. Cytokine 2009, 47(3):214-223.

[18] Dai ZJ, Wang XJ, Zhao Y, Ma XB, Kang HF, Min WL, Lin S, Yang PT, Liu XX: Effects of interleukin-10 polymorphisms (rs1800896, rs1800871, and rs1800872) on breast cancer risk: evidence from an updated meta-analysis. Genetic testing and molecular biomarkers 2014, 18(6):439-445.

[19] Giordani L, Bruzzi P, Lasalandra C, Quaranta M, Schittulli F, Della Ragione F, Iolascon A: Association of breast cancer and polymorphisms of interleukin-10 and tumor necrosis factoralpha genes. Clinical chemistry 2003, 49(10):1664-1667.

[20] Yu KD, Chen AX, Yang C, Fan L, Huang AJ, Shao ZM: The associations between two polymorphisms in the interleukin-10 gene promoter and breast cancer risk. Breast cancer research and treatment 2012, 131(1):27-31.

[21] Lis CG, Grutsch JF, Vashi PG, CA. L: Is serum albumin an independent predictor of survival in patients with breast cancer? J Parenter Enteral Nutr 2003, 27:10-15

[22] Cho YA, Sung MK, Yeon JY, Ro J, Kim J: Prognostic role of interleukin-6, interleukin-8, and leptin levels according to breast cancer subtype. Cancer research and treatment : official journal of Korean Cancer Association 2013, 45(3):210-219.

[23] Domingo-Domenech J, Oliva C, Rovira A, Codony-Servat J, Bosch M, Filella X, Montagut C, Tapia M, Campas C, Dang L et al: Interleukin 6, a nuclear factor-kappaB target, predicts resistance to docetaxel in hormone-independent prostate cancer and nuclear factor-kappaB inhibition by PS-1145 enhances docetaxel antitumor activity. Clinical cancer research: an official journal of the American Association for Cancer Research 2006, 12(18): 5578-5586. 